\title{
A new species of the millipede genus Circulocryptus Golovatch, 2016 from Western Malaysia (Diplopoda: Polydesmida: Cryptodesmidae)
}

\author{
Новый вид Аиплопод рода Circulocryptus Golovatch, 2016 из \\ Западной Малайзии (Diplopoda: Polydesmida: Cryptodesmidae)
}

\author{
S.I. Golovatch \\ С.И. Головач
}

Institute for Problems of Ecology and Evolution, Russian Academy of Sciences, Leninsky prospekt 33, Moscow 119071, Russia. Институт проблем экологии и эволюции РАН, Ленинский проспект, 33, Москва 119071, Россия.

KEY WORDS: Diplopoda, Cucrulocryptus, taxonomy, new species, Malaysia.

КЛЮЧЕВЫЕ СЛОВА: Diplopoda, Cucrulocryptus, таксономия, новый вид, Малайзия.

ABSTRACT. A new cryptodesmid is described from Western Malaysia: Circulocryptus magnus sp.n. It differs from all three hitherto known congeners by as few as 18 radii (and 19 sectors) at the anterior margin of the collum, four transverse rows of mostly setigerous tubercles/bosses on each postcollum metatergum and five lobulations at the lateral margin of each postcollum paratergum, the conspicuously inflated, glandular $\sigma^{7}$ femora 3, as well as certain minor details of gonopodal structure, in particular the remarkably prominent, broad, apicolateral lobe (lo) of the basal part (b) of the gonopodal telopodite.

РЕЗЮМЕ. ОПисан новый вид криптодесмид из Западной Малайзии: Circulocryptus magnus sp.n. Он отличается от всех трёх до сих пор известных видов рода всего лишь 18 радиусами (и 19 секторами) на переднем крае коллума, четырьмя поперечными рядами по большей части несущих щетинки бугорков на каждом метатергите позади коллума и пятью дольками на боковом крае каждого паратергита позади коллума, необычно сильно вздутыми железистыми бёдрами 3 самца, а также некоторыми мелкими деталями строения гоноподов, прежде всего, необычно крупной, широкой, вершинно-боковой пластиной (lo) основной части (b) телоподита гонопода.

\section{Introduction}

The small Oriental genus Circulocryptus Golovatch, 2016 has hitherto been known to comprise some three species: C. fallei Golovatch, 2016 (the type species) from southern Vietnam, C. javanicus Golovatch, 2017 from western Java, Indonesia, and $C$. kompantsevi Golovatch, 2018 from Cambodia [Golovatch, 2016, 2018a, b; Golovatch, VandenSpiegel, 2017]. This genus, together with the monobasic Carinocryptus Golovatch, 2018 from southern Vietnam, form a separate tribe, Circulocryptini, family Cryptodesmidae, characterized by bipartite gonopodal telopodites, in which their main branch carries a seminal groove running distad largely on the mesal side before moving onto a spiniform, lateral, retrorse solenomere. A slender solenophorous branch opposite the solenomere tip shows either a distinct (Circulocryptus) or underdeveloped (Carinocryptus) accessory seminal chamber and an accessory seminal duct [Golovatch, 2018b].

The present note puts on record a fourth species of Circulocryptus, this time from the Malay Peninsula, Western Malaysia. Some of the features observed in this beautiful new species, namely, the inflated $\sigma^{7}$ femora 3 , are so reminiscent of those seen in several species of the sympatric Oriental genus Ophrydesmus Cook, 1896 that the provisional assignment of a number of species to the latter genus is to be questioned [Golovatch, 2015].

\section{Material and methods}

The type series of the new Circulocryptus was borrowed from the collection of the Senckenberg Naturmuseum, Frankfurt a.M. (SMF), Germany. Except for a duplicate paratype retained for the holdings of the Zoological Museum of the Moscow State University (ZMUM), Russia, the entire series will be returned to the SMF.

Colour pictures were most skillfully taken and stacked by Kirill Makarov (Moscow, Russia).

How to cite this article: Golovatch S.I. 2018. A new species of the millipede genus Circulocryptus Golovatch, 2016 from Western Malaysia (Diplopoda: Polydesmida: Cryptodesmidae) // Russian Entomol. J. Vol.27. No.4. P.435-438. doi: 10.15298/rusentj.27.4.12 


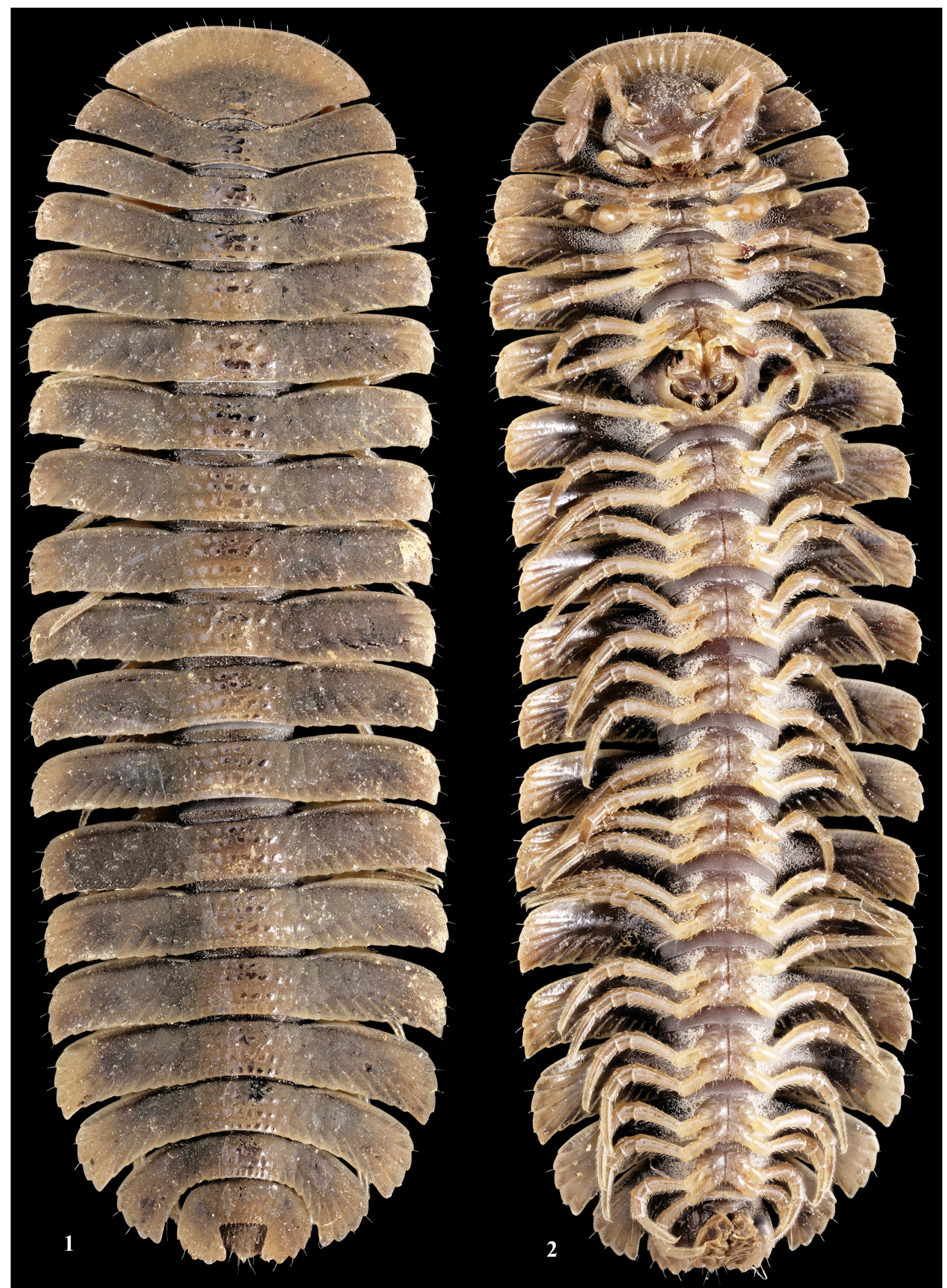

Figs 1-2. Habitus of Circulocryptus magnus sp.n., holotype $\odot^{7}$, dorsal and ventral views, respectively. Pictures taken by Kirill Makarov, not to scale. Рис. 1-2. Общий вид Circulocryptus magnus sp.n., голотип О’, соответственно сверху и снизу. Фотографии Кирилла Макарова, снято без масштаба. 


\section{Taxonomy}

\section{Circulocryptus magnus Golovatch, sp.n.} Figs 1-4.

HOLOTYPE $\sigma^{7}$ (SMF), Malaysia, Malay Peninsula, Pahang State, Fraser's Hill, ca 1300 m a.s.1., N 345'6.3', E 10145'9.86”, secondary forest, embankment along road, daytime and at night, by hand, 18-20.II.2015, leg. P. Jäger \& T. Laufs.

PARATYPES: 1 (ZMUM), same data, together with holo-

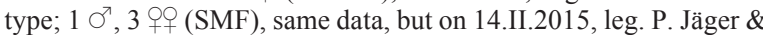
T. Laufs.

DIAGNOSIS. Using the latest key [Golovatch, 2018b], the new species differs from other species of Circulocryptus by as few as 18 radii (or 19 sectors) at the anterior margin of the collum, four transverse rows of mostly setigerous tubercles/bosses on each postcollum metatergum and five lobulations at the lateral margin of each postcollum paratergum, the conspicuously inflated, glandular $\sigma^{7}$ femora 3 , as well as certain minor details of gonopodal structure, in particular the remarkably prominent, broad, apicolateral lobe (lo) of the basal part (b) of the gonopodal telopodite.

NAME. To emphasize the relatively large size compared to some other congeners, including the conspicuously inflated $\sigma^{\top}$ femora 3 .
DESCRIPTION. Length ca 16 (holotype) to $17 \mathrm{~mm}$ ( $\sigma^{x}$ paratype) or 16-18 $\mathrm{mm}$ ( 9 paratypes), width of midbody proand metazonae 1.3 and $6.0 \mathrm{~mm}$, respectively (holotype), 1,4 and $6.0 \mathrm{~mm}$, respectively ( $\sigma^{7}$ paratype), $1.7-2.0$ and 5.0-6.0 $\mathrm{mm}$, respectively ( $\rightarrow$ paratypes). General coloration in alcohol (Figs 1-2) dark grey-brown to brown, including head, prozonae, sides below paraterga and venter, but anterior $1 / 3$ of collum, lateral $1 / 3$ of paraterga, legs and antennae lighter grey-brown. The latter increasingly infuscate distad, but tips pallid (Fig. 2).

Body with 20 segments. In width, head $<<$ collum $<$ segment $2<3<4=15$; thereafter body rapidly tapering towards telson. Head densely setose, labral region smooth and shining, between and behind antennae densely and clearly microgranulate, mostly dull; epicranial suture superficial, more distinct in vertigial region. Antennae short and densely setose, clearly clavate, C-shaped, antennomeres 1 and 2 lying inside a groove (Fig. 2); in length, antennomere $7<1=2=4$ $<6<3=5$; antennomeres 5 and 6 subequally high, each with a small, compact, apicodorsal group of minute bacilliform sensilla. Interantennal isthmus ca 1.8 times as broad as diameter of antennal socket.

Tegument mostly dull dorsally, only paraterga ventrally and sterna largely shining. prozonae very finely shagreened.

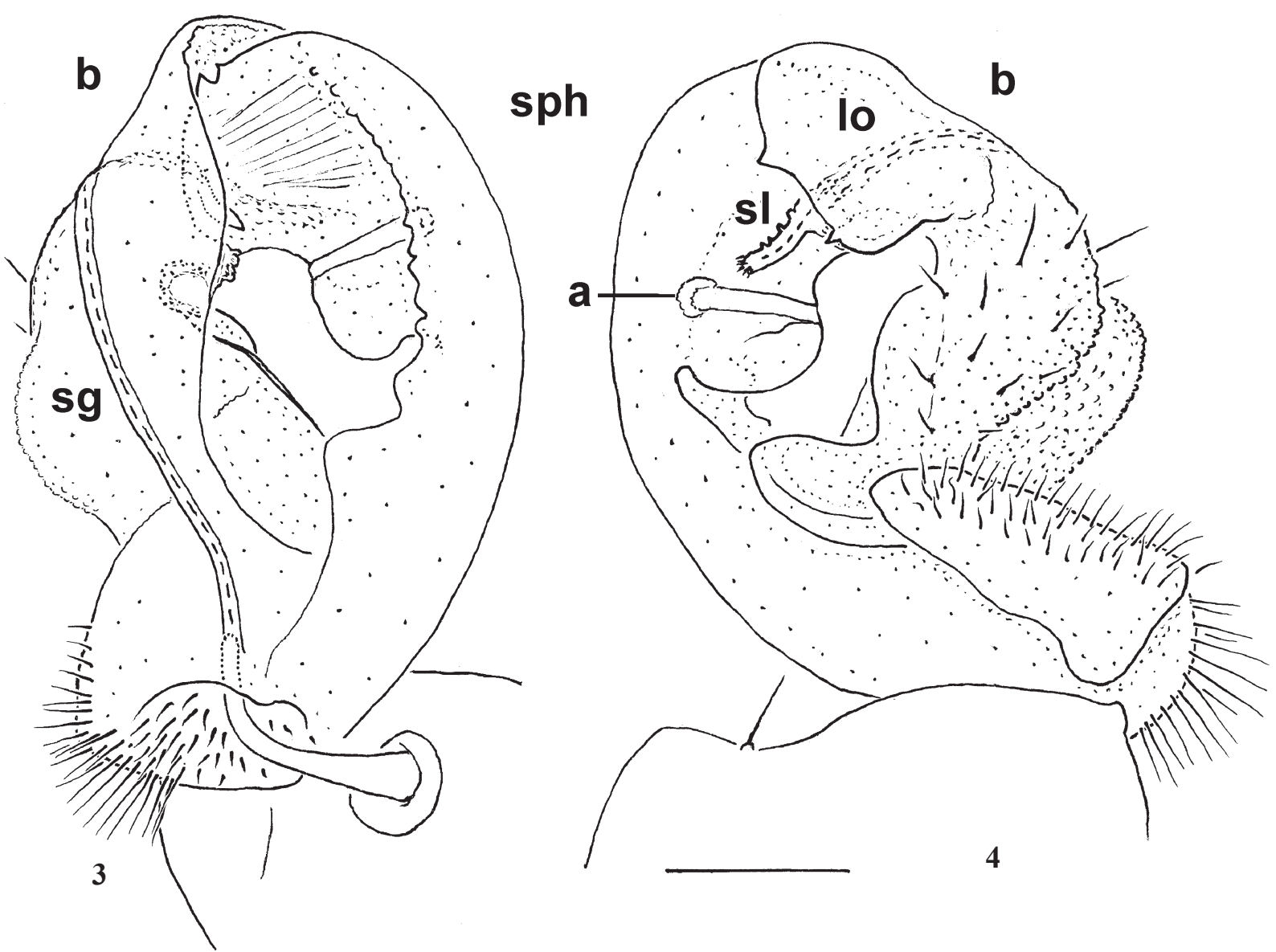

Figs 3-4. Right gonopod of Circulocryptus magnus sp.n., paratype $\sigma^{7}$, mesal and lateral views, respectively. Scale bar: 0.2 mm. Abbreviations: a — accessory seminal chamber; b — basal part; lo — apicolateral lobe; sg — seminal groove; sl — solenomere; sph — solenophore.

Рис. 3-4. Правый гонопод Circulocryptus magnus sp.n., паратип о, соответственно изнутри и сбоку. Масштаб: 0,2 мм. Сокращения: a - вспомогательная семенная камера; b — основная часть; lo — вершинно-боковая пластина; sg - семенная бороздка; sl - соленомер; sph - соленофор. 
Dorsum moderately and regularly convex; paraterga mostly set at about upper $1 / 3$ of body, very strongly developed, beginning with collum, regularly declined ventrad much like dorsum (Figs 1-2). Collum flabellate, completely covering the head from above, tauriform, anterior half as usual, flattened, posterior half slightly and regularly elevated, with 4 5 vague, transverse, irregular rows of small, mostly transverse, obliterated tuberculations; anterior margin regularly rounded, with 18 indistinct radii, or 19 equal sectors, each latter with a short apical seta. Postcollum paraterga very broad, flat, only slightly declined ventrad, each much broader than prozona; anterior margin/shoulder always entire, mostly nearly straight and narrowly bordered, increasingly, but faintly curved caudad towards telson, with neither radii nor crenulations; only anterolateral corner slightly rounded and typically bearing a particularly small lobulation, followed by three radii and four larger lobulations along a subquadrate lateral edge, caudal corner drawn increasingly behind rear tergal margin only in segments 15-19; paraterga 19 produced slightly behind tip of epiproct. Caudal margins of paraterga both radiate and increasingly strongly lobulate laterad, typically with 7-8+7-8 setigerous lobulations on each side before bases of paraterga, regardless of caudolateral ones (Figs 12). Mid-dorsal parts of metaterga with four transverse and regular rows of small, setigerous, mostly transverse, obliterated tubercles/knobs, caudal row being especially small. Tergal setae short, light, pointed, usually well visible, but often obliterate, $1 / 5-1 / 6$ as long as metatergite. Neither an axial line nor pleurosternal carinae. Ozopores invisible, pore formula untraceable. Stricture dividing pro- and metazonae narrow and shallow, microgranulate at bottom. Limbus brushlike, very densely microspiculate. Epiproct (Figs 1-2) coni$\mathrm{cal}$, dorsal and lateral tubercles evident. Hypoproct subtrapeziform, 1+1 caudal setae clearly separated, borne on evident tubercles (Fig. 2).

Sternites very narrow (Fig. 2), densely setose, deeply impressed along main axis, distinctly broadened only between $\sigma^{7}$ coxae 9. A small, but evident, rod-like, sternal tooth present only near each of $\sigma^{7}$ coxae 6 and 7 (Fig. 2). Epigynal ridge behind + legs 2 low, but evident, regularly rounded. Legs long and slender in both sexes, about as long as paraterga, densely setose, without modifications except for remarkably inflated, subspherical, glandular $\sigma^{7}$ femora 3 (Fig. 2); in length, tarsi $>$ femora $>>$ prefemora $=$ tibiae $>$ postfemora $=$ coxae; gonapophyses on $\sigma^{7}$ coxae 2 small cones; neither adenostyles nor tarsal brushes. Claws simple, slightly curved ventrad. Gonopod aperture subcordiform, caudal and lateral margins thin and slightly elevated (Fig. 2).

Gonopods (Figs 3-4) in situ held parallel to each other (Fig. 2). Telopodite typically subcircular, very strongly curved caudad, bipartite. Main, basal part (b) of telopodite slightly curved anteriad, subtruncate and extended apically into a very prominent apicolateral lobe (lo) and, in distal quarter, into a long, solid, subunciform, papillate, lateral solenomere (sl), the latter mostly concealed by lo. Seminal groove (sg) mostly mesal. A distinct accessory seminal chamber (a) and a short duct devoid of a hairy pulvillus lying in distal part of solenophore (sph) just opposite sl, branch $\mathbf{b}$ being subequal in length to branch sph.

REMARKS. Ophrydesmus is formally the most speciesrich genus of Oriental Cryptodesmidae. It presently counts 13 species, including several putative ones [Golovatch, 2015]. As only very few Ophrydesmus, including the type species, are characterized by the presence of an enlarged, glandular $\sigma^{7}$ femur 3 and a sternal tooth near each coxa, the modern diagnosis of the genus is based solely on gonopodal characters. Since Circulocryptus magnus sp.n. also demonstrates an enlarged, glandular $\sigma^{7}$ femur 3 and even a sternal tooth near each of $\sigma^{7}$ coxae 6 and 7, the identities of all putative and other poorly known Ophrydesmus require revision, in particular those few which are based on male material [Golovatch, 2015, 2018b].

Superficially, Circulocryptus magnus sp.n. bridges Circulocryptus and Ophrydesmus so strongly, that the gonopodal conformation remains the sole character to distinguish both these sympatric genera. Even an inflated $\sigma^{7}$ femur 3 proves to be shared by some of their species.

ACKNOWLEDGEMENTS. Infinite thanks are due to Peter Jäger and Julia Altmann (both SMF) for the financial and technical assistance to make my month long research visit to the SMF in July and August 2018 possible. Kirill V. Makarov (Moscow, Russia) very kindly helped me with photography.

\section{References}

Golovatch S.I. 2015. Review of the millipede genus Ophrydesmus Cook, 1896, with the description of a new species from southern Vietnam (Diplopoda: Polydesmida: Cryptodesmidae) // Tropical Natural History. Vol.15. No.2. P.155-165.

Golovatch S.I. 2016. The millipede family Cryptodesmidae in Indochina (Diplopoda: Polydesmida) // ZooKeys. Vol.578. P.3343. http://dx.doi.org/10.3897/zookeys.578.7994

Golovatch S.I. 2018a. Two new species of polydesmoid millipedes from western Java, Indonesia (Diplopoda: Polydesmida: Cryptodesmidae, Haplodesmidae)// Tropical Natural History. Vol.18. No.1. P.1-10.

Golovatch S.I. 2018b. Further notes on the millipede family Cryptodesmidae in Southeast Asia, with descriptions of a new genus and two new species from Indochina (Diplopoda: Polydesmida) // Raffles Bulletin of Zoology. Vol.66. P.361-370.

Golovatch S.I., VandenSpiegel D. 2017. One new and two littleknown species of the millipede family Cryptodesmidae from Indochina (Diplopoda, Polydesmida) // Zoologicheskii Zhurnal. Vol.96. No.7. P.757-767. 